\title{
Evaluation of a latex agglutination test for Rickettsia conorii antibodies in seropositive patients
}

\author{
L. DE LA FUENTE, P. ANDA*, I. RODRIGUEZ, K. E. HECHEMY†, D. RAOULT $\ddagger$ and J. CASAL
}

Servicio de Bacteriologia, Centro Nacional de Microbiologia, Virologia e Immunologia Sanitarias, Majadahonda, Madrid, Spain, †Wadsworth Center for Laboratories and Research, New York State Department of Health, Albany, New York 12201, USA, and $\ddagger$ Centre National de Référence des Rickettsioses, CHU TIMONE-13385Marseille cedex-5-, France

\begin{abstract}
Summary. A latex agglutination test for antibodies to Rickettsia conorii was compared with micro-immunofluorescence (the reference test for total antibodies); 179 sera were from 115 confirmed cases of Mediterranean Spotted Fever, and 101 were from pregnant women (control group) who had no detectable antibodies by the reference method. The micro-immunofluorescence test for specific IgM antibodies was used to clarify some discordant results. The agreement obtained between latex- $R$. conorii and micro-immunofluorescence was $95 \%$. Sensitivity and specificity were $96 \%$ and $93 \%$ respectively. When micro-immunofluorescence results for specific IgM antibodies were included, these figures rose to 96 and $99 \%$, and agreement was almost $97 \%$. Latex agglutination is a simpler and more rapid technique than micro-immunofluorescence and is suitable for the screening as well as for the titration of $R$. conorii antibodies.
\end{abstract}

\section{Introduction}

Several authors have reported a recent increase in the incidence of Mediterranean Spotted Fever (MSF) caused by Rickettsia conorii (Gross et al., 1982; Otero et al., 1982; Piras et al., 1982; Segura and Font, 1982; Mansuetto et al., 1986). The laboratory diagnosis of $R$. conorii infection is by total antibody detection by micro-immunofluorescence (micro-IF/Ig) (Philip et al., 1976). However, this test is expensive, slow, and requires experienced personnel and sophisticated equipment, and so is of limited use in many laboratories.

We made a preliminary evaluation of the Latex$R$. conorii agglutination test (LA) (Hechemy et al., 1980, 1986; Raoult et al., 1985) and compared our results with those obtained by micro-IF/Ig as the reference technique.

In this paper, we report studies of LA to establish whether it is sensitive and specific in comparison with micro-IF/Ig, and as easy to perform as any other agglutination test.

\section{Materials and methods}

\section{Sera}

A panel of 280 sera was used; 179 were from clinically

Received 9 Nov. 1987; revised version accepted 7 July 1988. diagnosed and laboratory confirmed MSF patients (115 cases), and 101 were from pregnant women with no detectable antibodies by micro-IF/Ig. The ages of patients and controls were similar. Samples were classified as acute (1-6 days after onset of symptoms), early convalescent ( $7-14$ days) or late convalescent ( $>14$ days). A single convalescent serum was available from 63 MSF patients; in 52 cases two or three consecutive sera were obtained.

\section{Micro-immunofluorescence (micro-IF)}

The micro-IF test was performed as previously described for $R$. rickettsii antibodies (Philip et al., 1976) with three determinations: micro-IF/Ig, micro-IF/IgM and micro-IF/IgG, for total specific antibodies, specific IgM, and specific IgG detection respectively. The antigen was purchased from bioMérieux, France, and the antihuman conjugates from Dako Immunochemicals, Denmark.

Interference of rheumatoid factor in the determination of anti- $R$. conorii IgM was avoided by the prior removal of IgG. The reagent was obtained from Behringwerke AG, Federal Republic of Germany.

\section{Latex agglutination}

The LA test was performed as described previously (Hechemy et al., 1980, 1986; Raoult et al., 1985) with reagents developed by one of us. 


\section{Analysis}

The sensitivity, specificity and correlation, as well as positive and negative predictive values, were calculated as previously described (Griner et al., 1981).

\section{Results}

\section{Comparison of $L A$ and micro- $I F / I g$}

Table I shows that of 280 serum samples, 145 gave positive results by both methods, five reacted only in micro-IF/Ig tests and nine only in LA tests. If the micro-IF/Ig results are considered to be the reference values, the overall sensitivity and predictive value for a positive result in the LA test were $96.7 \%$ and $94.2 \%$ and the specificity and negative predictive values $93.1 \%$ and $96.0 \%$ respectively. This specificity was a consequence of the samples with positive results by LA and negative results by micro-IF/Ig. The agreement between the two methods was $95.0 \%$.

Samples with discrepant results are shown in table II, which includes the consecutive samples where available.

\section{Comparison between $L A$, micro-IF/Ig and micro-IF/ IgM}

When specific IgM was tested for, the number of samples reactive only by micro-IF/Ig increased from 5 to 6 and the number of samples reactive only by LA decreased from nine to one (table I). Thus, some sera were found to be reactive by LA and micro-IF/IgM but not by micro-IF/Ig.

The sensitivity and positive predictive values for LA were $96.2 \%$ and $99.4 \%$ respectively. The slight decrease in the sensitivity was due to case 6 (table II), which gave a positive result by micro-IF/IgM but not by micro-IF/Ig.
The specificity and negative predictive values were $99.2 \%$ and $95 \cdot 2 \%$ respectively. The increased specificity of LA was due to acute samples from cases 8-15 (table II), which show low levels of specific IgM, as detected by micro-IF/IgM and LA. The agreement in this case was $97.5 \%$.

Agreement between titres obtained by LA and microIF/Ig

Antibody titres were usually lower by LA than by micro-IF/Ig, but there were some exceptions:

(a) Four samples, that gave negative results by LA but positive results by micro-IF/Ig, had titres of 40 and 80 . Two of them contained specific IgG and IgM and the other two only specific IgM (first samples of cases 1-4, table II).

(b) One sample, that gave a negative result by LA but a positive result by micro-IF/Ig at high titre, had a specific IgG response only, probably as a result of past MSF infection (case 5, table II).

(c) Of nine samples that gave positive results by LA but negative results by micro-IF/Ig, eight gave positive results by micro-IF/IgM (cases 715 , table II).

(d) Of eleven samples with a titre of 32 by LA and $\geqslant 320$ by micro-IF/Ig, eight contained specific IgG and IgM, two specific IgG only and one specific IgM only.

\section{Results with 52 paired sera}

Of 52 paired sera, $34(65.4 \%)$ seroconverted in both LA and micro-IF/Ig tests (32 with a specific IgM response). Six (11.5\%) seroconverted by microIF/Ig tests only (all contained specific IgM), with titres of 32 by LA. The other 12 paired sera showed

Table I. Comparison of LA and micro-IF/Ig with 280 sera

\begin{tabular}{|c|c|c|c|c|}
\hline \multirow[b]{3}{*}{ LA result } & \multicolumn{4}{|c|}{ Micro-IF/Ig result } \\
\hline & \multicolumn{2}{|c|}{ Positive } & \multicolumn{2}{|c|}{ Negative } \\
\hline & $\mathrm{IF} / \mathrm{Ig} \dagger$ & $\mathrm{IF} / \mathrm{Ig}+\mathrm{IF} / \mathrm{IgM} \ddagger$ & $\mathrm{IF} / \mathrm{Ig}$ & $\mathrm{IF} / \mathrm{Ig}+\mathrm{IF} / \mathrm{IgM}$ \\
\hline $\begin{array}{l}\text { Positive* } \\
\text { Negative }\end{array}$ & $\begin{array}{r}145 \\
5\end{array}$ & $\begin{array}{r}153 \\
6\end{array}$ & $\begin{array}{r}9 \\
121\end{array}$ & $\begin{array}{r}1 \\
120\end{array}$ \\
\hline
\end{tabular}


Table II. Cases with discrepant results in acute samples

\begin{tabular}{|c|c|c|c|c|c|c|c|c|c|}
\hline \multicolumn{5}{|c|}{ Micro-IF/Ig positive and LA negative } & \multicolumn{5}{|c|}{ Micro-IF/Ig negative and LA positive } \\
\hline Case no. & Phase & $\begin{array}{l}\text { Micro- } \\
\text { IF/Ig }\end{array}$ & $\begin{array}{l}\text { Micro- } \\
\text { IF/IgM }\end{array}$ & LA & Case no. & Phase & $\begin{array}{l}\text { Micro- } \\
\text { IF/Ig }\end{array}$ & $\begin{array}{l}\text { Micro- } \\
\text { IF/IgM }\end{array}$ & LA \\
\hline \multirow[t]{2}{*}{1} & $\begin{array}{c}\text { AS } \\
\text { LCS }\end{array}$ & $\begin{array}{r}40 \\
320\end{array}$ & + & $\overline{128}$ & 7 & $\begin{array}{c}\text { AS } \\
\text { LCS }\end{array}$ & $\overline{320}$ & $\overline{+}$ & $\begin{array}{r}32 \\
128\end{array}$ \\
\hline & LCS & 320 & + & 128 & 8 & $\begin{array}{l}\text { AS } \\
\text { LCS } \\
\text { LCS }\end{array}$ & $\begin{array}{l}\overline{160} \\
160\end{array}$ & $\begin{array}{l}+ \\
+ \\
+\end{array}$ & $\begin{array}{l}32 \\
32 \\
32\end{array}$ \\
\hline \multirow[t]{2}{*}{2} & $\begin{array}{l}\text { ECS } \\
\text { LCS } \\
\text { LCS }\end{array}$ & $\begin{array}{r}80 \\
320 \\
640\end{array}$ & - & $\begin{array}{l}\overline{128} \\
256\end{array}$ & 9 & $\begin{array}{l}\text { AS } \\
\text { LCS } \\
\text { LCS }\end{array}$ & $\begin{array}{l}-\overline{80} \\
80\end{array}$ & $\begin{array}{l}+ \\
+ \\
+\end{array}$ & $\begin{array}{r}32 \\
128 \\
128\end{array}$ \\
\hline & & & & & 10 & $\begin{array}{c}\text { AS } \\
\text { LCS }\end{array}$ & $\geqslant \overline{320}$ & + & $\begin{array}{r}32 \\
128\end{array}$ \\
\hline \multirow[t]{2}{*}{3} & $\begin{array}{l}\text { ECS } \\
\text { LCS }\end{array}$ & $\begin{array}{r}40 \\
320\end{array}$ & - & $\overline{64}$ & 11 & $\begin{array}{c}\text { AS } \\
\text { LCS }\end{array}$ & $\overrightarrow{160}$ & $\begin{array}{l}+ \\
+\end{array}$ & $\begin{array}{l}32 \\
32\end{array}$ \\
\hline & & & & & 12 & $\begin{array}{c}\text { AS } \\
\text { LCS }\end{array}$ & $\overline{80}$ & $\begin{array}{l}+ \\
+\end{array}$ & $\begin{array}{l}32 \\
32\end{array}$ \\
\hline 4 & LCS & 80 & + & - & 13 & $\begin{array}{c}\text { AS } \\
\text { LCS }\end{array}$ & $\geqslant \overline{320}$ & + & $\begin{array}{r}32 \\
256\end{array}$ \\
\hline 5 & ECS & 320 & - & - & 14 & $\begin{array}{c}\text { AS } \\
\text { LCS }\end{array}$ & $\overline{160}$ & + & $\begin{array}{l}32 \\
32\end{array}$ \\
\hline 6 & $\begin{array}{c}\text { AS } \\
\text { LCS }\end{array}$ & $\geqslant \overline{320}$ & $\begin{array}{l}+ \\
+\end{array}$ & $\overline{256}$ & 15 & $\begin{array}{l}\text { AS } \\
\text { LCS } \\
\text { LCS }\end{array}$ & $\begin{array}{l}\overline{80} \\
80\end{array}$ & $\begin{array}{l}+ \\
+ \\
+\end{array}$ & $\begin{array}{l}32 \\
32 \\
32\end{array}$ \\
\hline
\end{tabular}

AS $=$ Acute sample.

ECS $=$ Early convalescent sample.

LCS $=$ Late convalescent sample.

rising titres by both tests and specific IgM was detected in 10 of them.

\section{Discussion}

Comparisons of the $\mathrm{LA}$ and micro- $\mathrm{IF} / \mathrm{Ig}$ tests showed good values for sensitivity $(96.7 \%)$ specificity $(93.1 \%)$ and predictive value. However, some discrepant results were found, mostly in acute samples.

Discrepancies in acute sera (nine positive by LA only) could suggest that LA is less specific than micro-IF/Ig. However, the positive micro-IF/IgM reaction in eight of them suggests that the microIF/Ig is less sensitive than LA. Indeed, the predictive value of a positive result increased from $94.2 \%$ to $99 \cdot 4 \%$ and the specificity obtained when comparing LA with micro-IF/Ig rose from 93.1 to $99.2 \%$ when micro-IF/IgM was included. We attribute this discrepancy to the greater sensitivity of FITC-antihuman IgM conjugate than FITCantihuman $\operatorname{Ig} G+\operatorname{Ig} M+\operatorname{Ig} A$ in the very early phase of the disease, when low levels of IgM and negative $\mathrm{IgG}$ would be expected.
On the other hand, the finding of samples reactive only by micro-IF/Ig and not LA has been described already for $R$. rickettsii (Hechemy et al., 1983a,b) and for $R$. conorii (Raoult et al., 1985). The microIF test measures antibodies to some heat-labile protein antigens not present in the erythrocytesensitising substance (ESS) used to coat the latex particles, since ESS is prepared by boiling the microorganism (Hechemy et al., 1983a).

Elderly MSF patients would also be expected to exhibit this pattern of discrepancy. These results suggest that LA may be useful in the early diagnosis of MSF.

Both LA and micro-IF/IgM results were similar in these samples. This could be because LA is as able to detect specific IgM as other agglutination tests. The pentameric nature of $\operatorname{IgM}$ molecules needs a low antibody concentration to show visible agglutination.

LA and micro-IF/Ig also differ in the time of appearance of antibodies. In some cases, detectable antibodies appeared earlier by LA than by microIF/Ig; in all of these, except case 7 (table II), microIF/IgM was also positive. In other cases the opposite 
was found. However, no such differences were seen in an earlier report (Raoult et al., 1985). Fuller evaluation of serial samples collected during the acute phase would be necessary to shed further light on this observation.

Latex $R$. conorii titres were generally one dilution step lower than micro-IF/Ig titres. However, some LA titres varied by two dilution steps or more. Low levels of IgM gave LA-positive but micro-IF/Ignegative results. Two sera gave positive micro-IF/ IgG and IgM but negative LA results. The lack of a response to some outer antigens present only in the micro-IF preparations, or some factors in those sera that may inhibit agglutination of the coated latex particles, could explain this observation (Hechemy et al., 1983a).

Greater variations between titres by both tests (a titre of $\geqslant 320$ by micro-IF/Ig but negative by LA (in case 5, table II) could be the result of past MSF infection.

\section{REFERENCES}

Griner P F, Mayewski R J, Mushlin A I, Greenland P 1981 Selection and interpretation of diagnostic tests and procedures. Annals of Internal Medicine 94: 553-600.

Gross E M, Yagupsky P, Torok V, Goldwasser R A 1982 Resurgence of Mediterranean Spotted Fever. Lancet 2: 1107.

Hechemy K E, Anacker R L, Carlo N L, Fox J A, Gaafar H A $1983 a$ Absorption of Rickettsia rickettsii antibodies by Rickettsia rickettsii antigens in four diagnostic tests. Journal of Clinical Microbiology 17: 445-449.

Hechemy K E et al. 1980 Detection of Rocky Mountain Spotted Fever antibodies by a latex agglutination test. Journal of Clinical Microbiology 12: 144-150.

Hechemy K E et al. 1983 b Evaluation of latex-Rickettsia rickettsii test for Rocky Mountain Spotted Fever in 11 laboratories. Journal of Clinical Microbiology 18: 938-946.

Hechemy K E, Raoult D, Eisemann C, Han Y S, Fox J A 1986 Detection of antibodies to Rickettsia conorii with a latex agglutination test in patients with Mediterranean Spotted Fever. Journal of Infectious Diseases 153: 132-135.
In six cases, sero conversion was only demonstrated by micro-IF/Ig, in the presence of a positive titre for LA. This suggests that very early samples, collected no later than the onset of the disease, may be necessary to show sero conversion by LA. Four of these cases showed a rise in titre from 32 to 64 , an observation not included in our evaluation because a twofold rise in titre is not generally regarded as significant.

In summary, LA shows promise for screening and titration because of its sensitivity, specificity and agreement with the reference test. It is also simpler and more rapid than micro-IF/Ig and can be performed in laboratories without specially trained personnel or sophisticated equipment.

We are grateful to Dolores Muñoz Chaves and Pilar Sagüés Tornos for secretarial assistance and to Fernando Barta Martinez for his help in the translation of the text.

Mansuetto S, Tringali G, Walker D H 1986 Widespread, simultaneous increase in the incidence of Spotted Fever Group Rickettsioses. Journal of Infectious Diseases 154: 539-540.

Otero R, Fenoll A, Casal J 1982 Resurgence of Mediterranean Spotted Fever. Lancet 2: 1107.

Philip R N, Casper E A, Ormsbee R A, Peacock M G, Burgdorfer W 1976 Microimmunofluorescence test for the serological study of Rocky Mountain Spotted Fever and Typhus. Journal of Clinical Microbiology 3: 51-61.

Piras M A, Gakis C, Budroni M, Andreoni G 1982 Immunological studies in Mediterranean Spotted Fever. Lancet 1: 1249.

Raoult D, Hechemy K E, Chaudet H 1985 Sérologie de la Fièvre Boutonneuse méditerranéenne. Cinétique des anticorps détectés par trois méthodes: L'immunofluorescence indirecte, l'hémagglutination indirecte, et l'agglutination Latex. Pathologie Biologie 33: 839-841.

Segura F, Font B 1982 Resurgence of Mediterranean Spotted Fever in Spain. Lancet 2: 280. 